\title{
Annual Report on the External Quality Assessment Scheme for Tumor Markers in Korea (2017)
}

\section{Sang Hoon Song \\ Department of Laboratory Medicine, Seoul National University Hospital, Seoul National University College of Medicine, Seoul, Korea}

Corresponding author: Sang Hoon Song Department of Laboratory Medicine, Seoul National University Hospital, Seoul National University College of Medicine, 101 Daehak-ro, Jongno-gu, Seoul 03080, Korea Tel: $+82-2-2072-3326$

Fax: +82-2-747-0359

E-mail: cloak21@snu.ac.kr
In 2017, the tumor marker program of the Korean Association of External Quality Assessment Service was performed for tumor markers I and II. Tumor marker I comprised alphafetoprotein (AFP), carcinoembryonic antigen, protein induced by vitamin $\mathrm{K}$ absence-II, and prostate specific antigen (PSA), and tumor marker II comprised cancer antigen (CA) 125, CA 19-9, CA 15-3, CA 72-4, and beta-2-microglobulin. Two challenges were conducted with three pooled serum or control materials, except for the first tumor marker I challenge. In total, 648 institutions participated in tumor marker I and 380 in tumor marker II programs. The response rates were $92.9 \%-97.0 \%$. The coefficients of variation (CVs) were different depending on tests and samples, and average CVs were $3.7 \%-16.8 \%$. The average CV of CA 72-4 tests, whose number of participants was the smallest, was the lowest. The average CV of AFP tests, which included a sample with very high levels, was the highest.

(J Lab Med Qual Assur 2018;40:70-76)

Key Words: Proficiency testing, Tumor marker, Korean Association of External Quality Assessment Service
서론

2017년 차세대 신빙도조사사업의 종양표지자검사 프로 그램은 종양표지자 I과 종양표지자 II로 구성하여 운영하였 다. 총 9종의 검사항목에 대하여 시행하였으며, 종양표지자 I 에는 alpha-fetoprotein (AFP), carcinoembryonic antigen (CEA), prostate specific antigen (PSA), protein induced by vitamin $\mathrm{K}$ absence or antagonist-II (PIVKA-II)검사가 포함되어 있었으며, 종양표지자 II에는 cancer antigen (CA) 125, CA 19-9, CA 15-3, CA 72-4, beta2-microglobulin (B2M)이 포함되어 있었다. 이에 2017년 종양표지자 신빙도 조사사업의 결과를 요약하고 발전방향을 모색하고자 한다.

\section{재료 및 방법}

종양표지자검사 프로그램에서는 상반기와 하반기로 나누어 총 2회 외부정도관리물질을 발송하였으며, 각 회차 당 2-3개 의 외부정도관리물질을 평가하도록 하였다.
종양표지자 I을 위한 외부정도관리물질은 직접 조제하였다. 혈액원으로부터 구입한 fresh-frozen plasma를 $-70^{\circ} \mathrm{C}$ 이하 에 보관하다 조제 직전 해동하였다. 해동한 혈장에 고농도의 잔여 검체를 혼합하여 1 회차는 2 가지, 2 회차는 3 가지 농도의 외부정도관리물질을 조제하였다. 잔여 검체 혼합 후 $4^{\circ} \mathrm{C}$ 냉장 실에서 교반기를 이용하여 16 시간 이상 혼합하였다. 혼합 혈 장은 $3,000 \mathrm{rpm}$ 에서 10 분간 원심분리한 후 잔여 침전물을 제 거하기 위해 $0.2 \mu \mathrm{m}$ 필터로 잔여 침전물을 제거하였다. 잔여 검체는 $\mathrm{AFP}, \mathrm{CEA}, \mathrm{PSA}, \mathrm{PIVKA}-\mathrm{II}$ 검사가 의뢰되어 검사를 실시한 후의 잔여 검체 중 고농도의 검체를 수집하여 $4^{\circ} \mathrm{C}$ 에서 냉장 보관하였다. 조제한 외부정도관리물질은 농도별로 각각 $1 \mathrm{~mL}$ 씩 분주하여 냉동보관 후 기관에 발송하였다.

종양표지자 II를 위한 외부정도관리물질은 Lyphochek Tumor Marker Plus Control (Bio-Rad, Hercules, CA, $\mathrm{USA}$ ) 물질을 이용하였다. 각 회차마다 낮은 농도, 중간 농도, 높은 농도의 물질로 구성하여 기관에 발송하였다.

외부정도관리물질은 계약 택배를 이용하여 발송하였는데, 종양표지자 I은 1 회차는 4 월 24 일에, 2 회차는 10 월 16 일에, 종 
양표지자 II는 1회차는 3월 20일에, 2회차는 9월 18일에 발송 하였다, 검사결과는 차세대 신빙도조사사업 홈페이지에 입력 하도록 하였고, 입력기간 종료 후 데이터 오류를 검증한 후 통 계분석을 시행하였다.

통계분석은 전체 기관, 제조회사별, 측정기기별로 시행하였 다. 검사항목 및 회차별로 평균(mean), 표준편차(standard deviation), 변이계수(coefficient of variation), 중앙값 (median), 최소값(min), 최대값(max)을 구하였다. Standard deviation index (SDI)는 제조회사와 장비별로 산출하였다. 평균, 표준편차, 변이계수는 참여기관의 75 pertentile 값(Q3) 과 25 percentile 값(Q1)의 차(Q3-Q1; interquartile range, $\mathrm{IQR})$ 의 1.5 배를 초과하여 Q1보다 낮거나 Q3보다 높은 결과 값(Q1-1.5×IQR 또는 $\mathrm{Q} 3+1.5 \times \mathrm{IQR})$ 은 이상치(outlier)로 제가한 후 분석하였다. 참여기관의 수가 10 개 이상인 경우에 는 SDI를 산출하였으나, 10 개 미만인 경우에는 $\mathrm{SDI}$ 를 산출하 지 않고 중앙값, 최소값, 최대값만을 산출하였다. 참여기관의 수가 2개 이하인 경우에는 SDI, 중앙값을 산출하지 않고 최소 값과 최대값만을 산출하였다[1,2].

\section{결과 및 고찰}

\section{1. 신빙도조사사업 참여기관}

2017년 종양표지자검사 프로그램은 종양표지자 I은 668 기관, 종양표지자 II는 397기관이 신청하여 검체를 발송하였 다. 종양표지자 I은 1회차에 627기관(93.9\%), 2회차 648기 관(97.0\%)에서 회신하였다. 종양표지자 II는 1회차 369기관 (92.9\%), 2회차 380기관(95.7\%)에서 회신하였다.

\section{2. 종양표지자검사의 제조사 현황}

종양표지자검사의 결과를 회신한 기관은 모두 면역측정 장비를 사용하고 있었으며 제조사별로 분류할 때 Roche (Mannheim, Germany)가 가장 많았고, Abbott (Abbot Park, IL, USA), Siemens (Tarrytown, NY, USA), Beckman Coulter (Brea, CA, USA), bioMerieux (Marcy L'Etoile, France), Fujirebio (Tokyo, Japan), Ortho Clinical Diagnostics (Raritan, NJ, USA), Tosoh (Tokyo, Japan), DiaSorin (Dietzenbach, Germany), Wako (Osaka, Japan) 등의 제조사 장비도 2 기관 이상에서 사용하고 있었다. 총 9 개 의 종양표지자검사에서 PIVKA-II와 B2M을 제외하고 7개 검 사에서 Roche 장비를 사용하는 기관이 가장 많았다. PIVKAII는 Wako 또는 Abbott, B2M은 Biomerieux 장비를 사용하 는 기관이 가장 많았다. Table 1에 참여기관의 종양표지자 검

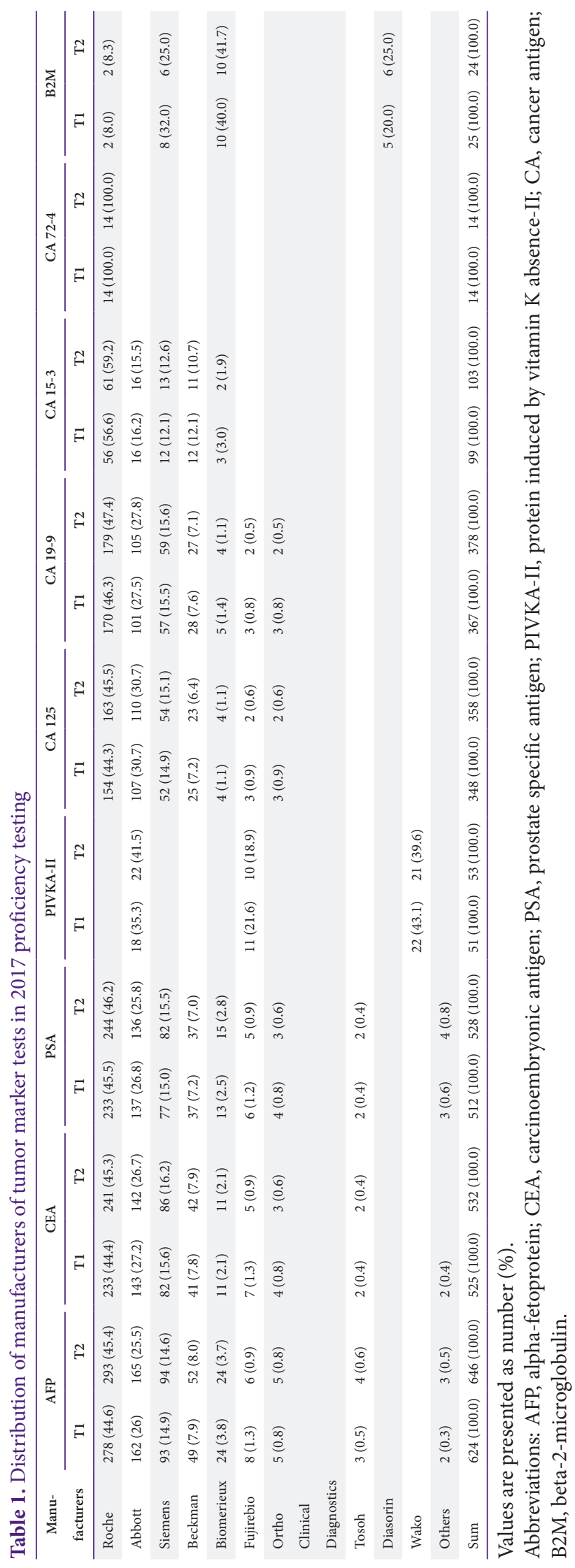




\section{Journal of LABORATORY MEDICINE and QUALITY ASSURANCE}

Sang Hoon Song • Report on EQA for Tumor Markers

Table 2. 2017 proficiency testing results for tumor marker tests

\begin{tabular}{|c|c|c|c|c|c|c|c|c|c|c|c|}
\hline \multirow[b]{2}{*}{ Test name } & \multirow[b]{2}{*}{ Sample no. } & \multirow{2}{*}{$\begin{array}{c}\text { No. of } \\
\text { participants }\end{array}$} & \multirow[b]{2}{*}{ Mean } & \multirow[b]{2}{*}{ Average } & \multirow[b]{2}{*}{ CV (\%) } & \multirow[b]{2}{*}{ Median } & \multirow[b]{2}{*}{ Min } & \multirow[b]{2}{*}{ Max } & \multicolumn{3}{|c|}{ Outliers (\%) } \\
\hline & & & & & & & & & All & $\begin{array}{l}\text { Manu- } \\
\text { facturer }\end{array}$ & $\begin{array}{c}\text { Instru- } \\
\text { ment }\end{array}$ \\
\hline \multirow[t]{5}{*}{$\operatorname{AFP}(n g / m L)$} & CT1-17-01 & 627 & 2.44 & 0.22 & 9.0 & 2.4 & 0.0 & 189.1 & 11.2 & 7.2 & 5.2 \\
\hline & CT1-17-02 & 627 & 215.16 & 19.29 & 9.0 & 210.9 & 1.9 & 306.3 & 1.9 & 5.6 & 5.5 \\
\hline & CT1-17-03 & 648 & 9.89 & 0.72 & 7.3 & 9.9 & 0.8 & 2523.5 & 5.4 & 6.8 & 5.3 \\
\hline & CT1-17-04 & 648 & 351.41 & 28.10 & 8.0 & 349.0 & 10.3 & 880.6 & 3.4 & 6.3 & 6.4 \\
\hline & CT1-17-05 & 648 & $1,900.96$ & 686.19 & 36.1 & $2,000.0$ & 10.2 & $3,434.0$ & 0.0 & 3.6 & 5.0 \\
\hline \multirow[t]{5}{*}{ CEA (ng/mL) } & CT1-17-01 & 526 & 1.25 & 0.22 & 17.8 & 1.3 & 0.0 & 11.5 & 3.6 & 6.5 & 5.0 \\
\hline & CT1-17-02 & 526 & 3.67 & 0.42 & 11.3 & 3.7 & 0.0 & 5.1 & 1.7 & 6.7 & 5.0 \\
\hline & CT1-17-03 & 536 & 9.63 & 1.92 & 19.9 & 10.3 & 2.4 & 14.5 & 0.7 & 6.2 & 4.6 \\
\hline & CT1-17-04 & 536 & 4.18 & 0.27 & 6.4 & 4.1 & 1.0 & 7.2 & 17.5 & 5.6 & 4.2 \\
\hline & CT1-17-05 & 536 & 6.72 & 0.51 & 7.5 & 6.8 & 1.0 & 11.3 & 11.9 & 9.2 & 3.8 \\
\hline \multirow[t]{5}{*}{ PSA (ng/mL) } & CT1-17-01 & 513 & 0.65 & 0.06 & 9.8 & 0.7 & 0.4 & 6.0 & 2.5 & 5.7 & 6.1 \\
\hline & CT1-17-02 & 513 & 3.68 & 0.26 & 7.1 & 3.7 & 0.4 & 5.0 & 9.0 & 7.0 & 6.5 \\
\hline & CT1-17-03 & 530 & 0.51 & 0.06 & 11.2 & 0.5 & 0.3 & 467.0 & 1.9 & 2.7 & 3.8 \\
\hline & CT1-17-04 & 530 & 0.76 & 0.07 & 9.4 & 0.8 & 0.5 & 731.0 & 3.2 & 2.5 & 2.1 \\
\hline & CT1-17-05 & 530 & 4.34 & 0.36 & 8.3 & 4.4 & 0.5 & 6.7 & 5.8 & 5.5 & 3.8 \\
\hline \multirow{5}{*}{$\begin{array}{l}\text { PIVKA-II } \\
(\mathrm{mAU} / \mathrm{mL})\end{array}$} & CT1-17-01 & 51 & 16.90 & 1.70 & 10.2 & 17.0 & 11.0 & 22.0 & 13.7 & 2.0 & 2.0 \\
\hline & CT1-17-02 & 51 & 343.00 & 37.40 & 10.9 & 352.0 & 285.0 & 416.0 & 0.0 & 3.9 & 3.9 \\
\hline & CT1-17-03 & 53 & 31.70 & 2.90 & 9.0 & 32.0 & 26.0 & 36.0 & 0.0 & 0.0 & 0.0 \\
\hline & CT1-17-04 & 53 & 421.00 & 64.80 & 15.4 & 445.0 & 332.0 & 550.0 & 0.0 & 0.0 & 0.0 \\
\hline & CT1-17-05 & 53 & $1,543.50$ & 213.30 & 13.8 & $1,634.0$ & $1,207.0$ & $1,891.0$ & 0.0 & 7.5 & 5.8 \\
\hline \multirow[t]{6}{*}{ CA $125(\mathrm{U} / \mathrm{mL})$} & CT2-17-01 & 350 & 33.97 & 5.19 & 15.3 & 33.1 & 9.9 & 194.8 & 0.9 & 5.7 & 6.4 \\
\hline & CT2-17-02 & 350 & 105.16 & 17.35 & 16.5 & 102.1 & 38.4 & 365.0 & 0.6 & 4.6 & 4.1 \\
\hline & CT2-17-03 & 350 & 216.55 & 39.68 & 18.3 & 208.6 & 0.0 & 402.6 & 4.9 & 5.7 & 5.3 \\
\hline & CT2-17-04 & 360 & 34.65 & 5.51 & 15.9 & 32.7 & 12.8 & 46.2 & 0.3 & 5.6 & 5.7 \\
\hline & CT2-17-05 & 360 & 84.98 & 15.29 & 18.0 & 80.5 & 30.7 & 207.9 & 0.3 & 7.8 & 6.8 \\
\hline & CT2-17-06 & 360 & 237.26 & 46.79 & 19.7 & 221.5 & 75.6 & 356.1 & 0.0 & 7.3 & 5.1 \\
\hline \multirow[t]{6}{*}{ CA $19-9(\mathrm{U} / \mathrm{mL})$} & CT2-17-01 & 369 & 27.82 & 2.47 & 8.9 & 27.8 & 14.3 & 37.4 & 5.1 & 5.7 & 6.4 \\
\hline & CT2-17-02 & 369 & 71.79 & 10.01 & 13.9 & 74.5 & 37.3 & 230.8 & 1.9 & 5.4 & 4.7 \\
\hline & CT2-17-03 & 369 & 201.58 & 28.87 & 14.3 & 208.1 & 0.0 & 314.5 & 2.7 & 7.9 & 6.4 \\
\hline & CT2-17-04 & 380 & 30.15 & 3.87 & 12.8 & 30.4 & 14.8 & 42.6 & 0.3 & 5.6 & 5.9 \\
\hline & CT2-17-05 & 380 & 70.17 & 11.38 & 16.2 & 75.4 & 36.7 & 215.9 & 0.5 & 5.3 & 6.7 \\
\hline & CT2-17-06 & 380 & 217.92 & 14.87 & 6.8 & 216.3 & 79.7 & 327.6 & 7.1 & 8.5 & 6.5 \\
\hline \multirow[t]{6}{*}{ CA $15-3(\mathrm{U} / \mathrm{mL})$} & CT2-17-01 & 101 & 23.65 & 2.59 & 10.9 & 24.3 & 10.2 & 28.0 & 5.0 & 5.1 & 2.1 \\
\hline & CT2-17-02 & 101 & 52.74 & 3.78 & 7.2 & 53.4 & 22.7 & 72.9 & 10.9 & 9.1 & 6.3 \\
\hline & CT2-17-03 & 101 & 101.52 & 7.16 & 7.1 & 102.1 & 38.1 & 117.0 & 11.9 & 6.1 & 4.2 \\
\hline & CT2-17-04 & 105 & 23.39 & 2.39 & 10.2 & 24.1 & 8.9 & 33.1 & 6.7 & 8.7 & 5.0 \\
\hline & CT2-17-05 & 105 & 57.04 & 3.45 & 6.0 & 57.1 & 23.3 & 83.4 & 14.3 & 9.7 & 5.9 \\
\hline & CT2-17-06 & 105 & 112.81 & 5.62 & 5.0 & 112.9 & 40.8 & 304.5 & 19.0 & 10.7 & 11.9 \\
\hline
\end{tabular}


Journal of LABORATORY MEDICINE and QUALITY ASSURANCE

Sang Hoon Song • Report on EQA for Tumor Markers

Table 2. Continued

\begin{tabular}{|c|c|c|c|c|c|c|c|c|c|c|c|}
\hline \multirow[b]{2}{*}{ Test name } & \multirow[b]{2}{*}{ Sample no. } & \multirow{2}{*}{$\begin{array}{c}\text { No. of } \\
\text { participants }\end{array}$} & \multirow[b]{2}{*}{ Mean } & \multirow[b]{2}{*}{ Average } & \multirow[b]{2}{*}{ CV (\%) } & \multirow[b]{2}{*}{ Median } & \multirow[b]{2}{*}{ Min } & \multirow[b]{2}{*}{$\operatorname{Max}$} & \multicolumn{3}{|c|}{ Outliers (\%) } \\
\hline & & & & & & & & & All & $\begin{array}{l}\text { Manu- } \\
\text { facturer }\end{array}$ & $\begin{array}{c}\text { Instru- } \\
\text { ment }\end{array}$ \\
\hline \multirow[t]{6}{*}{ CA $72-4(\mathrm{U} / \mathrm{mL})$} & CT2-17-01 & 14 & 4.62 & 0.25 & 5.4 & 4.6 & 4.3 & 5.2 & 0.0 & 0.0 & 0.0 \\
\hline & CT2-17-02 & 14 & 11.66 & 0.49 & 4.2 & 11.8 & 10.9 & 12.3 & 0.0 & 0.0 & 0.0 \\
\hline & CT2-17-03 & 14 & 40.51 & 0.81 & 2.0 & 40.5 & 37.1 & 42.2 & 7.1 & 7.1 & 0.0 \\
\hline & CT2-17-04 & 14 & 5.41 & 0.18 & 3.4 & 5.5 & 5.1 & 5.7 & 0.0 & 0.0 & 0.0 \\
\hline & CT2-17-05 & 14 & 14.54 & 0.54 & 3.7 & 14.6 & 13.6 & 15.6 & 0.0 & 0.0 & 0.0 \\
\hline & CT2-17-06 & 14 & 49.01 & 1.43 & 2.9 & 48.6 & 44.9 & 51.4 & 7.1 & 7.1 & 0.0 \\
\hline \multirow[t]{6}{*}{ B2M (mg/L) } & CT2-17-01 & 27 & 1.62 & 0.17 & 10.7 & 1.7 & 1.3 & 1.9 & 0.0 & 4.0 & 4.5 \\
\hline & CT2-17-02 & 27 & 3.81 & 0.32 & 8.4 & 3.9 & 2.9 & 4.3 & 0.0 & 0.0 & 4.5 \\
\hline & CT2-17-03 & 27 & 6.06 & 0.62 & 10.3 & 6.1 & 4.0 & 7.1 & 3.7 & 4.0 & 4.5 \\
\hline & CT2-17-04 & 27 & 1.53 & 0.24 & 15.8 & 1.6 & 1.0 & 2.0 & 0.0 & 12.5 & 9.1 \\
\hline & CT2-17-05 & 27 & 3.74 & 0.19 & 5.2 & 3.7 & 2.9 & 4.9 & 18.5 & 4.2 & 9.1 \\
\hline & CT2-17-06 & 27 & 5.88 & 0.53 & 9.0 & 6.0 & 4.8 & 7.6 & 3.7 & 4.2 & 4.5 \\
\hline
\end{tabular}

Abbreviations: CV, coefficients of variation; AFP, alpha-fetoprotein; CEA, carcinoembryonic antigen; PSA, prostate specific antigen; PIVKAII, protein induced by vitamin $\mathrm{K}$ absence-II; CA, cancer antigen; B2M, beta-2-microglobulin.

사항목별 제조사 현황을 정리하였다.

\section{3. 종양표지자검사 신빙도조사사업 결과}

총 9 개의 종양표지자검사를 대상으로 2 회에 걸쳐 총 5 개의 검체, 즉 45 개 결과값의 분포를 분석한 결과 종양표지자검사 전체의 평균 변이계수는 $10.8 \%$ 였다. 이 중 가장 낮은 변이계 수를 나타낸 경우는 CT2-17-03 검체의 CA 72-4였고, 가장 낮 은 변이계수를 나타낸 경우는 CT1-17-05 검체의 AFP였다. $\mathrm{CA} 72$-4의 경우 참여기관이 사용하고 있는 제조사가 1 개이 므로 변이계수가 가장 낮은 값을 보인 것으로 추정되며, CT1$17-05$ 검체의 AFP는 평균 농도가 $1,900.96 \mathrm{ng} / \mathrm{mL}$ 로 매우 높 은 값이어서 제조사, 장비별 보정물질의 범위, 희석 여부, 희석 방법 등에 따라 차이가 크게 난 것으로 추정된다. 변이계수가 크므로 이상치의 비율이 높을 것으로 예상할 수도 있으나 표준 편차가 크기 때문에 이상치로 제거된 자료의 비율은 다른 검 사 또는 검체에 비해 낮았다. 향후에 임상적으로 나타날 수 있 는 매우 낮은 값 또는 높은 값을 이용한 외부정도관리를 확장 한다면 이러한 현상의 현황을 파악하기 용이할 것으로 생각된 다. 이상치로 제거된 결과의 비율은 평균 $5 \%$ 내외였는데 어 떤 기준을 적용하느냐에 따라서 매우 큰 차이가 나는 검사 또 는 검체가 있었다. 예를 들면, CT1-17-01 검체에서 PIVKA-II 의 경우 이상치의 비율이 참여기관 전체를 peer group으로 형 성할 때는 $13.7 \%$, 제조사 또는 장비를 기준으로 peer group 을 할 때는 $2.0 \%$ 로 참여기관 전체를 기준으로 할 때 6 배 이상
Table 3. Coefficients of variation of tumor marker tests in 2017 proficiency testing (\%)

\begin{tabular}{lc}
\hline \multicolumn{1}{c}{ Test name } & $\begin{array}{c}\text { Mean } \pm \\
\text { standard deviation }\end{array}$ \\
\hline Alpha-fetoprotein & $13.9 \pm 12.4$ \\
Carcinoembryonic antigen & $12.6 \pm 6.1$ \\
Prostate specific antigen & $9.2 \pm 1.6$ \\
Protein induced by vitamin K absence-II & $11.9 \pm 2.7$ \\
CA 125 & $16.8 \pm 1.3$ \\
CA 19-9 & $13.2 \pm 2.7$ \\
CA 15-3 & $8.3 \pm 2.1$ \\
CA 72-4 & $3.7 \pm 1.2$ \\
Beta-2-microglobulin & $10.1 \pm 3.9$ \\
\hline
\end{tabular}

Abbreviation: CA, cancer antigen.

이상치의 비율이 높았다. CT1-17-05 검체에서 AFP의 경우 이상치의 비율이 참여기관 전체를 peer group으로 형성할 때 는 $0 \%$, 제조사를 기준으로 peer group을 할 때는 $3.6 \%$, 장비 를 기준으로 peer group을 할 때는 $5.0 \%$ 로 전체보다는 제조 사, 장비 간 차이가 큰 경향이 있었다. 이상치로 제거된 결과의 비율은 전체 $4.5 \%$ ) 또는 장비 $(4.5 \%)$ 기준일 때보다는 제조사 $(5.4 \%)$ 를 기준으로 할 때가 약간 높은 경향이 있었다. 그러나, 전체를 기준으로 하는 경우 이상치로 제거되는 비율의 변동이 가장 심하여서 특정한 제조사의 결과가 다른 제조사들과 크게 차이가 나는 경우 전체를 기준으로 하는 산출에서 제외될 가능 
A

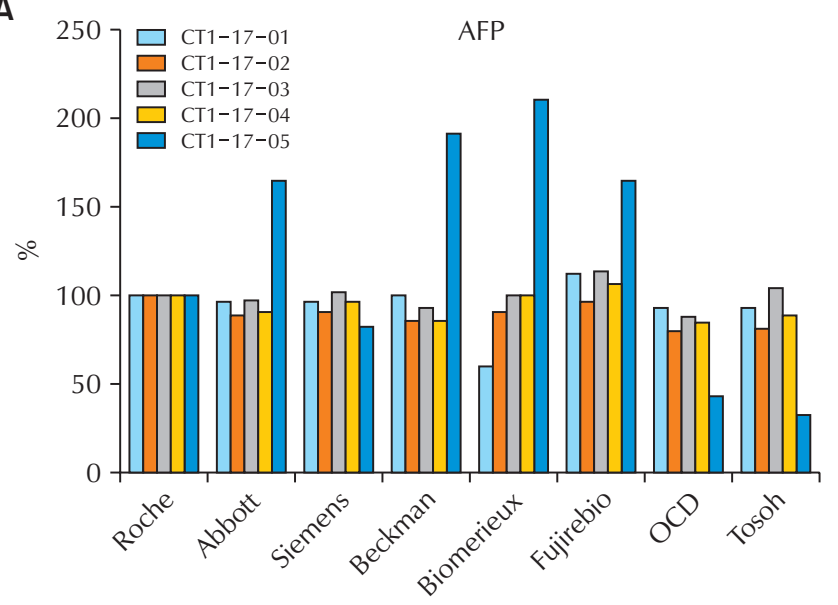

C

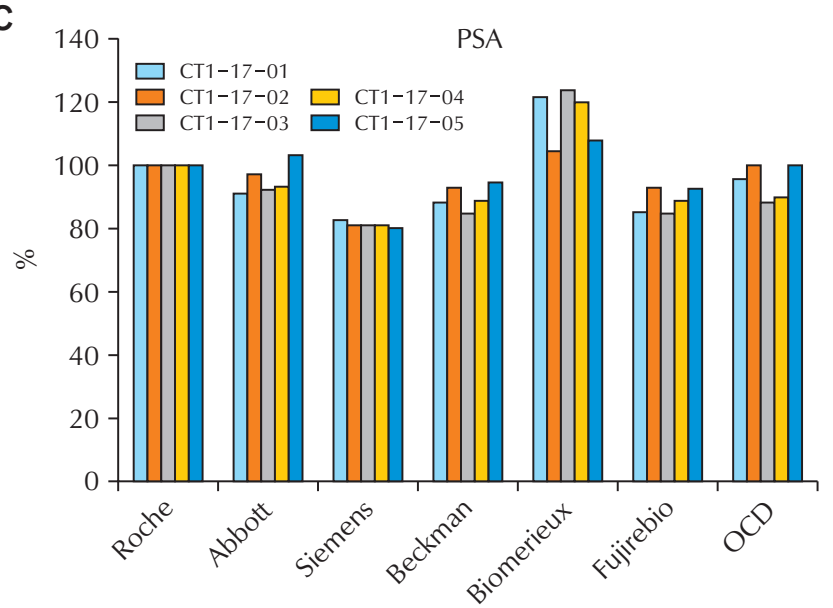

E

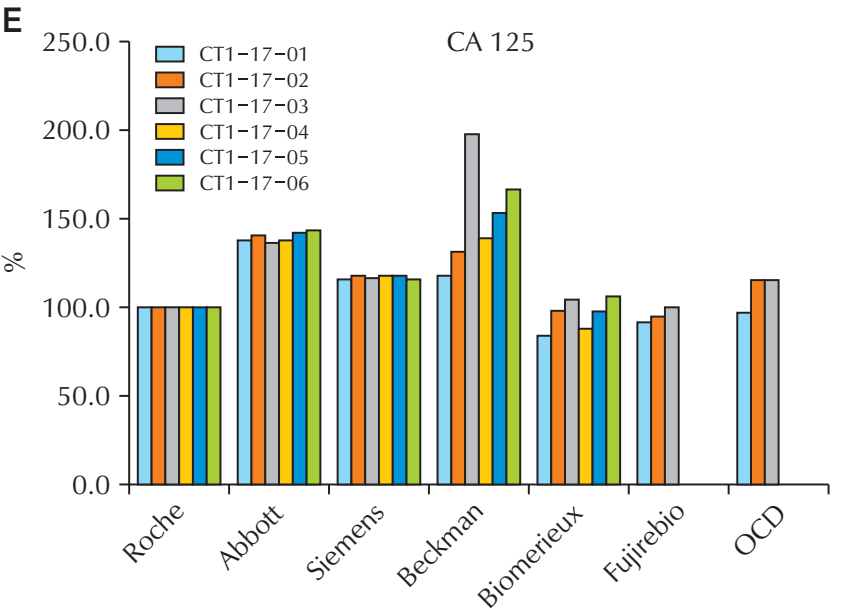

B

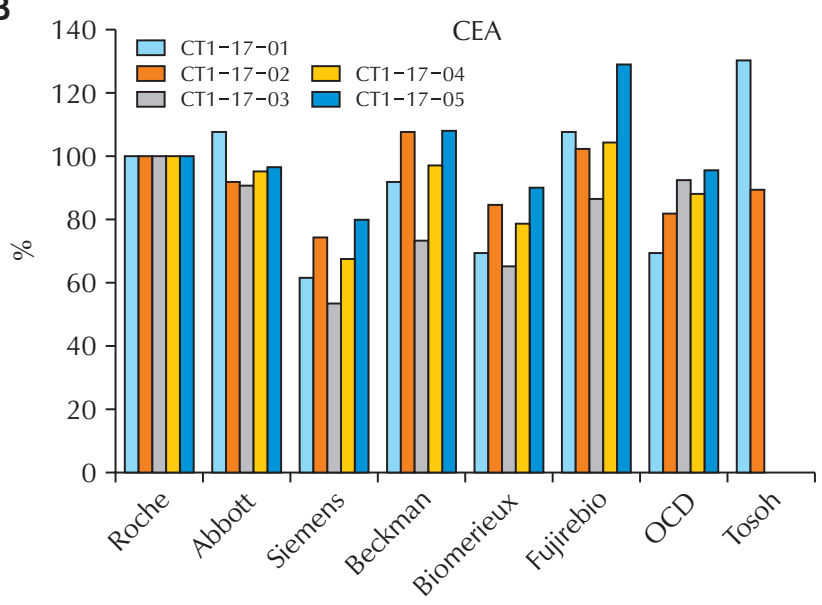

D

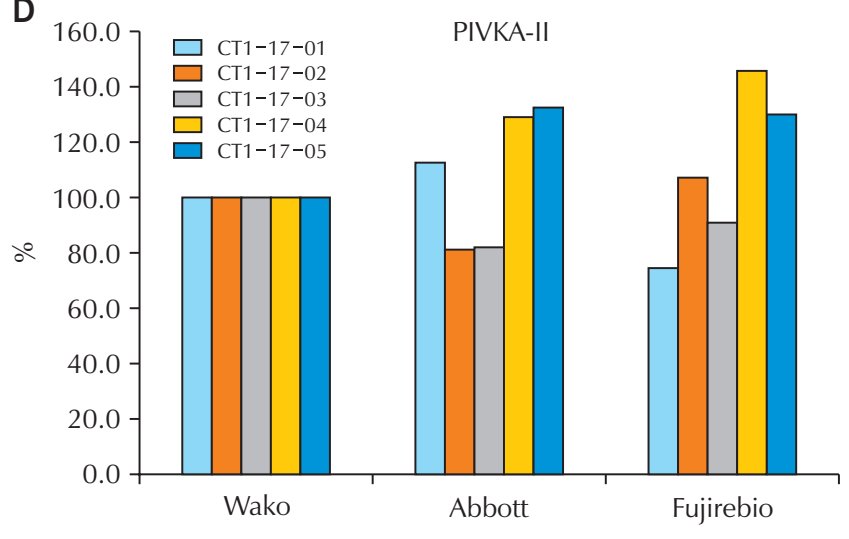

F

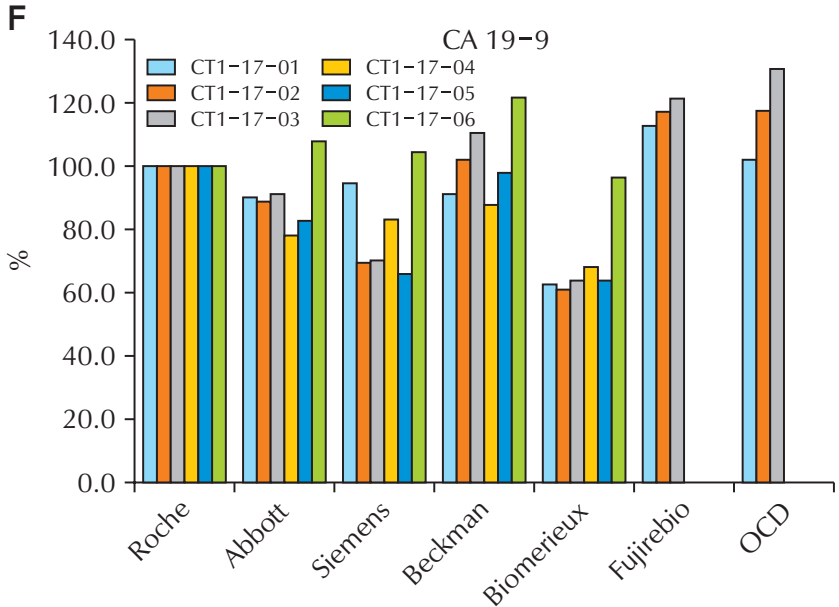

Fig. 1. (A-H) Manufacturer-dependent differences in tumor marker tests in 2017 proficiency testing. The median values from manufacturers with the largest participant numbers were fixed as $100 \%$ and the ratios to remaining manufacturers were calculated. Abbreviations: AFP, alpha-fetoprotein; CEA, carcinoembryonic antigen; PSA, prostate specific antigen; PIVKA-II, protein induced by vitamin $\mathrm{K}$ absence-II; CA, cancer antigen; B2M, beta-2-microglobulin. 


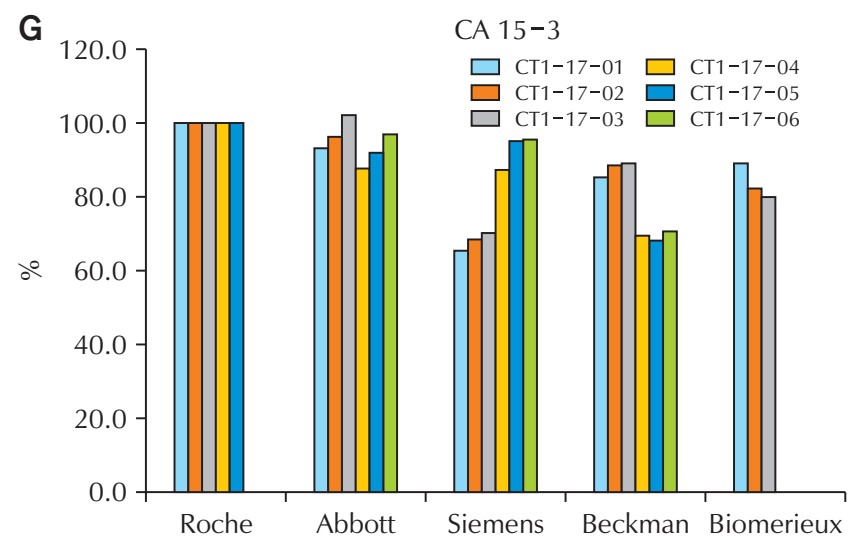

Fig. 1. Continued

성이 높다는 것을 추정할 수 있다. 특히 참여기관의 수가 적은 제조사일수록 전체를 기준으로 할 때 이상치로 제거될 가능성 이 높다고 할 수 있다. 이러한 현상은 앞으로 일치화 또는 표준 화 시 참고할 수 있을 것으로 생각된다. Table 2에 검사별, 검 체별 구체적인 자료를 정리하였다.

종양표지자검사별로는 CA 72-4의 평균 변이계수가 3.7\% 로 가장 낮았고, $\mathrm{CA} 125$ 의 평균 변이계수가 $16.8 \%$ 로 가장 높 았다. CA 72-4의 변이계수가 낮은 결과는 예측 가능하였으 나, CA 125 에서 변이계수가 높은 결과는 예측하지 못한 결과 였다. 이러한 현상은 검체와 농도에 상관없이 유사하게 관찰되 었는데, 이는 CA 125 의 제조사 간 차이가 다른 검사에 비해서 큼을 시사한다고 할 수 있다. Table 3에 검사별 변이계수의 분 포를 정리하였다.

종양표지자검사의 제조사 간 차이는 검사종류와 검체에 따 라 다른 양상을 나타냈는데, 변이계수가 가장 큰 검체인 CT117-05에서 그 차이가 가장 두드러지게 나타났다. Fig. 1에 종 양표지자 검사별 제조사 중앙값의 차이를 표시하였다.

2017년 종양표지자검사의 신빙도조사사업에서는 종양표지 자 I은 정상인 혈장과 환자 혈청을 이용하여 조제한 물질을 발

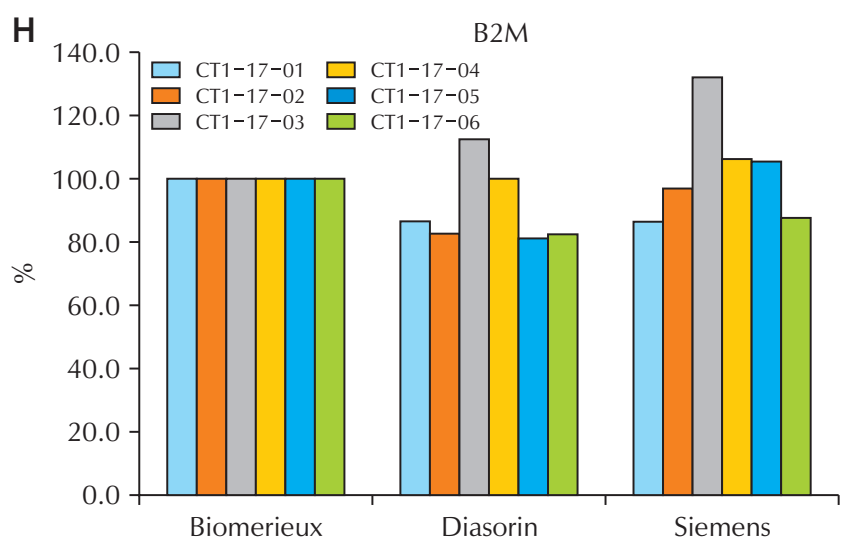

송했는데, 종양표지자 II와 변이계수의 분포가 유사하여 상용 화된 물질과 유사한 성능을 나타냄을 확인할 수 있었다. 신빙 도조사물질을 직접 조제하는 것은 분석물질의 농도를 다양화 함으로써 실제 임상적으로 의미 있는 여러 농도를 평가하거나 검출한계 또는 측정범위에 관한 자료를 축적할 수 있는 장점이 있다. 안정성, 균질성을 확보할 수 있다면 종양표지자 II로도 확대할 수 있을 것으로 생각된다.

\section{REFERENCES}

1. Lee YK; Routine Hematology Program, Korean Association of External Quality Assessment Service. Annual report on the external quality assessment scheme for routine hematology in Korea (2016). J Lab Med Qual Assur 2017;39:53-60.

2. Lee YW, Jeon BR, Kim JG, Jun SH, Yun YM, Chun S, et al. Annual report on the external quality assessment scheme for routine clinical chemistry in Korea (2016). J Lab Med Qual Assur 2017;39:61-75. 
Journal of LABORATORY MEDICINE and QUALITY ASSURANCE

Sang Hoon Song • Report on EQA for Tumor Markers

\section{종양표지자검사 프로그램 신빙도조사 결과보고(2017) 송상훈 \\ 서울대학교 의과대학 서울대학교병원 진단검사의학과}

2017년도 대한임상검사정도관리협회 종양표지자 프로그램에서는 종양표지자 과 종양표지자 ॥ 로 나누어 alpha-fetoprotein (AFP), carcinoembryonic antigen, prostate specific antigen, protein induced by vitamin K absence-\|, cancer antigen (CA) 125, CA 19-9, CA 15-3, CA 72-4, beta2-microglobulin 등 총 9종의 검사에 대하여 신빙도조사를 시행하였다. 총 2회 시행하였으며, 1회차 종양표지자 1 을 제외하고, 각 회차에 3 개의 물질을 발송하였다. 종양표지자 은 총 648기관, 종양표 지자 $\|$ 는 총 380기관이 참여하였으며 회신율은 92.9\%-97.0\%였다. 변이계수는 검사종류와 검체에

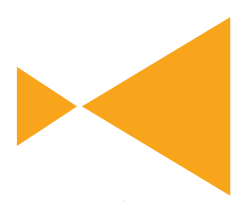

Journal of LABORATORY MEDICINE and

QUALITY ASSURANCE 따라 다르게 나타났는데 평균 변이계수는 3.7\%-16.8\%였다. 제조사가 1개인 CA 72-4의 변이계수 가 가장 낮았고 매우 높은 농도가 포함된 AFP의 변이계수가 가장 높았다.

(J Lab Med Qual Assur 2018;40:70-76)

교신저자: 송상훈

우)03080 서울시 종로구 대학로 101 , 서울대학교 의과대학 서울대학교병원 진단검사의학과

Tel: 02)2072-3326, Fax: 02)747-0359, E-mail: cloak21@snu.ac.kr 